\title{
ANALISIS BIOEKONOMI SUMBERDAYA IKAN PELAGIS KECIL DI KECAMATAN TEHORU KABUPATEN MALUKU TENGAH
}

\author{
Deby, M. Kewilaa \\ Sekolah Tinggi Keguruan dan Ilmu Pendidikan Saumlaki (STKIPS), \\ debykewilaa86@gmail.com
}

\begin{abstract}
Abstrak
Sumberdaya ikan pelagis kecil merupakan salah satu sumberdaya ikan yang paling melimpah di perairan Indonesia. Hampir seluruh hasil tangkapan ikan pelagis kecil yang didaratkan di Indonesia dikonsumsi lokal karena harganya relatif murah dan rasanya enak, sehingga diduga kontribusinya terhadap pemenuhan kebutuhan protein dari ikan bagi masyarakat sangatlah nyata. Seiring dengan meningkatnya kebutuhan akan ikan pelagis kecil ini, maka kelestariannya perlu dijaga agar dapat dimanfaatkan secara terus menerus dan dapat dinikmati oleh generasi yang akan datang. Berdasarkan laporan statistik Dinas perikanan Maluku Tengah, Kecamatan Tehoru merupakan salah satu lokasi berkembangnya perikanan tradisional di wilayah Kabupaten Maluku Tengah, ditunjukkan dengan beragamnya alat tangkap yang digunakan untuk menangkap berbagai macam jenis ikan termasuk di dalamnya adalah ikan pelagis kecil. Berdasarkan laporan statistik Dinas perikanan Maluku Tengah, perkembangan produksi di Kecamatan Tehoru selama tahun 2005 - 2011, pemanfatan ikan pelagis kecil mengalami fluktuasi produksi yaitu produksi tertinggi ikan pelagis kecil Tahun 2005 sebesar 437,530 dan produksi terendah pada Tahun 2011 sebesar 193,75 ton. Berdasarkan data tersebut terkait dengan potensi dan kondisi sumberdaya perikanan ikan pelagis kecil perlu dilakukan upaya pengelolaan yg optimal dan berkelanjutan serta terjaminnya kelestarian sumberdaya. Untuk itu menjadi dasar penelitian mengenai menganalisis bioekonomi ikan pelagis kecil yang ditemukan di Kecamatan Tehoru. Menganalisis keadaan bioekonomi sumberdaya ikan pelagis kecil di Kecamatan Tehoru dengan memakai indikator MSY dan MEY. Metode yang digunakan adalah menggunakan perhitungan pendugaan parameter biologi dan pendugaan parameter ekonomi. Hail penelitian menunjukkan bahwa tingkat produksi optimal pada pemanfaatan sumberdaya ikan pelagis kecil MSY di peroleh sebesar 301 ton per tahun dengan (Emsy) purse seine sebesar 103 trip per tahun. Hasil analisis Maximum Economic Yield (MEY) untuk ikan pelagis kecil di Kecamatan Tehoru menunjukkan produksi optimum sebanyak $299 \mathrm{~kg}$ pertahun dan Effort Maximum Economic Yield (EMEY) 99,85 trip per tahun jumlah trip penangkapan dengan MEY menunjukkan produksi optimum sebanyak $299 \mathrm{~kg}$ pertahun.
\end{abstract}




\section{Pendahuluan}

Sumberdaya ikan laut merupakan aset bangsa yang harus dimanfaatkan secara bijaksana, walaupun sumberdaya tersebut bersifat dapat pulih (renewable). Namun tingkat kecepatan pemeliharaanya dapat saja tidak seimbang dengan laju pemanfaatannya, karena pemanfaatan yang berlebihan terjadi bila jumlah ikan yang tertangkap telah melebihi kemampuan sumberdaya ikan dalam melakukan rekruitment. Bila upaya penangkapan tidak ditata dengan baik maka intensitas penangkapan akan terus meningkat, sehingga penurunan produksi tangkapan per upaya akan terus berlanjut hingga akhirnya merusak sumberdaya ikan dan lingkungannya (Namsa, 2006).

Prinsip dasar dalam pengelolaan sumberdaya ikan adalah bagaimana memanfaatkan sumberdaya ikan yang tidak hanya menghasilkan manfaat ekonomi yang tinggi bagi pengguna, namun tetap menjaga kelestariannya (keberlanjutan). Clark (1985) mengungkapkan bahwa pendekatan bioekonomi adalah pendekatan yang memadukan kekuatan ekonomi yang mempengaruhi industri penangkapan dan faktor biologi yang menentukan produksi suplai ikan. Pemakaian konsep ekonomi dimaksudkan untuk optimalisasi pemanfaatan sumberdaya ikan berdasarkan tinjauan ekonomi. Lebih lanjut dikatakan bahwa pendekatan bioekonomi merupakan suatu bentuk pendekatan yang mengakomodasikan harga yang berubah karena perubahan volume produksi. Selain itu melalui pendekatan bioekonomi dapat diketahui profitabilitas dan produktifitas dari nelayan.

Sumberdaya ikan pelagis kecil merupakan salah satu sumberdaya ikan yang paling melimpah di perairan Indonesia. Hampir seluruh hasil tangkapan ikan pelagis kecil yang didaratkan di Indonesia dikonsumsi lokal karena harganya relatif murah dan rasanya enak, sehingga diduga kontribusinya terhadap pemenuhan kebutuhan protein dari ikan bagi masyarakat sangatlah nyata. Seiring dengan meningkatnya kebutuhan akan ikan pelagis kecil ini, maka kelestariannya perlu dijaga agar dapat dimanfaatkan secara terus menerus dan dapat dinikmati oleh generasi yang akan datang.

Ikan pelagis umumnya senang bergerombol, baik dengan kelompoknya maupun dengan jenis ikan lainnya. Ikan pelagis merupakan ikan yang hidup pada 
lapisan permukaan perairan yang hidup pada lapisan permukaan perairan sampai tengah (mid layer). Pada daerah - daerah dimana terjadi proses kenaikan masa air (upwelling), sumberdaya ini dapat membentuk biomassa yang besar. Beberapa contoh ikan pelagis kecil antara lain layang (Decapterus spp), kembung (Rastrelliger sp), siro (Amblygaster sirm), selar (Selaroides sp), tembang (Sardinella fimbriata), dan teri (Stolephorus spp).

Berdasarkan laporan statistik Dinas perikanan Maluku Tengah, Kecamatan Tehoru merupakan salah satu lokasi berkembangnya perikanan tradisional di wilayah Kabupaten Maluku Tengah, ditunjukkan dengan beragamnya alat tangkap yang digunakan untuk menangkap berbagai macam jenis ikan termasuk di dalamnya adalah ikan pelagis kecil. Berdasarkan laporan statistik Dinas perikanan Maluku Tengah, perkembangan produksi di Kecamatan Tehoru selama tahun 2005 - 2011, pemanfatan ikan pelagis kecil mengalami fluktuasi produksi yaitu produksi tertinggi ikan pelagis kecil Tahun 2005 sebesar 437,530 dan produksi terendah pada Tahun 2011 sebesar 193,75 ton. Berdasarkan data tersebut terkait dengan potensi dan kondisi sumberdaya perikanan ikan pelagis kecil perlu dilakukan upaya pengelolaan yg optimal dan berkelanjutan serta terjaminnya kelestarian sumberdaya. Untuk itu menjadi dasar penelitian mengenai menganalisis bioekonomi ikan pelagis kecil yang ditemukan di Kecamatan Tehoru.

\section{Metode Penelitian}

Penelitian ini dilaksanakan di Wilayah Kecamatan Tehoru Kabupaten Maluku Tengah. Metode penelitian yang digunakan adalah metode survei, yaitu penelitian yang dilakukan dengan mengambil sampel melalui wawancara secara langsung dengan menggunakan kuesioner sebagai alat pengumpul data pokok (Singarimbun dan Effendi, 2008). Teknik wawancara dan observasi langsung pada lokasi penangkapan ikan. Teknik penetapan sampling lokasi/wilayah dilakukan secara purposive didasarkan pada potensi dan daya dukung pengembangan komoditi sumberdaya ikan.

\section{Metode Pengumpulan Data}

Data yang dibutuhkan dalam penelitian ini meliputi data primer dan data 
sekunder. Data primer diperoleh melalui wawancara langsung dengan nelayan serta observasi langsung di lapangan. Sedangkan data sekunder diperoleh melalui pihak - pihak yang ada hubungannya dengan penelitian ini, meliputi; Kantor Kecamatan Tehoru, BPS Maluku Tengah, DKP Maluku Tengah dan TPI di Kecamatan Tehoru.

\section{Teknik Analisa Data}

Analisa data merupakan bagian yang sangat penting dalam penelitian, karena hasilnya memberikan arti dan makna yang berguna untuk memecahkan masalah dalam penelitian (Nazir, 1999). Analisis data pada penelitian ini menggunakan analisa kuantitatif dan kualitatif.

\section{Pendugaan parameter biologi}

Pendugaan parameter biologi ini dilakukan menggunakan metode surplus produksi. Metode surplus produksi adalah metode yang digunakan untuk menghitung potensi lestari (MSY) dan upaya optimum dengan cara menganalisa hubungan upaya tangkap (E) dengan hasil tangkap per unit tangkap (CPUE) pada suatu perairan dengan data time series. Data yang digunakan berupa data hasil tangkap (catch) dan upaya tangkap (effort).
Menurut Schafer (1957), hubungan hasil tangkap (catch) dengan upaya tangkap (effort) adalah :

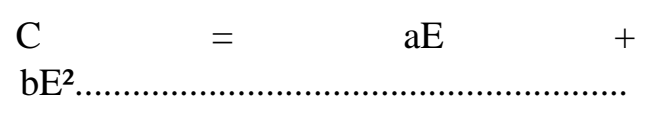

$$
\begin{array}{cc}
\text { dimana }: \mathrm{a}=\text { intercept } & \mathrm{b}=\text { slope } \\
\mathrm{C}=\text { total hasil tangkapan } & \mathrm{E}=\text { total } \\
\text { upaya penangkapan } &
\end{array}
$$

Sedangkan hubungan CPUE dengan upaya tangkap adalah :

$\begin{array}{lll}\text { CPUE } & =\end{array}$ bE.

Upaya tangkap optimum dihitung dengan merumuskan persamaan 1 terhadap upaya tangkap;

$\mathrm{dC} / \mathrm{dE}=\mathrm{a}+2 \mathrm{bE}$

$$
\begin{aligned}
0 & =a+2 b E \\
-2 b E & =a
\end{aligned}
$$

$$
\text { 『 E】_opt }=-\mathrm{a} / 2 \mathrm{~b}
$$

dimana E_opt = upaya penangkapan optimum Perhitungan nilai MSY dilakukan dengan memasukkan persamaan 2 ke dalam persamaan 1 sehingga diperoleh kondisi MSY :

$$
\text { C_(MSY )= }
$$

$a^{2} / 4 b$.

Dimana C_(MSY )= total hasil tangkapan pada kondisi lestari maksimum

$$
\text { C adalah tangkapan ikan (catch), }
$$
yaitu keseluruhan hasil tangkapan suatu jenis ikan, sedangkan $\mathrm{E}$ adalah upaya 
penangkapan ikan (effort), yaitu keseluruhan jumlah upaya penangkapan ikan yang digunakan menangkap suatu jenis ikan tertentu.

Biasanya untuk menunjukkan upaya penangkapan yang dimaksud digunakan jumlah trip penangkapan suatu armada penangkapan ikan. Akan tetapi bila jumlah trip penangkapan sulit ditemukan, maka dapat dipergunakan jumlah armada penangkapan ikan. Kelemahannya adalah tidak bisa menggambarkan berapa banyak upaya penangkapan yang dilakukan setiap kapal.

\section{Pedugaan parameter ekonomi}

Model Gordon Schaefer digunakan untuk menganalisis model bioekonomi purse seine. Model bioekonomi yang digunakan adalah model bioekonomi statik dengan harga tetap. Model ini disusun dari model paremeter biologi, biaya operasi penangkapan dan harga ikan.

Asumsi yang dipergunakan dalam model statik Gordon Schaefer ini adalah harga ikan per $\mathrm{Kg}$ (p) dan biaya penangkapan per unit upaya penangkapan adalah konstan. Total penerimaan nelayan dari uasaha penangkapan (TR) adalah :

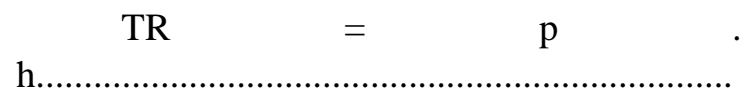

..(4)

dimana :

$\mathrm{TR}=$ Total Revenue (total penerimaan)

$\mathrm{P}=$ harga rata - rata ikan hasil survey per $\mathrm{kg}$ (Rp)

$\mathrm{h}=$ Jumlah produksi ikan $(\mathrm{kg})$
Total biaya penangkapan (TC) dihitung dengan persamaan :

$\mathrm{TC} \quad \mathrm{C} \quad \mathrm{C}$

dimana :

$\mathrm{TC}=$ Total cost

$\mathrm{C}=$ total pengeluaran rata - rata unit penangkapan ikan (Rp)

$\mathrm{E}=$ Jumlah upaya penangkapan untuk menangkapa sumberdaya ikan (unit)

Sehingga keuntungan bersih usaha penangkapan ikan $(\pi)$ adalah :

$\pi=\mathrm{TR}-\mathrm{TC}$

$\pi=\mathrm{p} . \mathrm{h}-\mathrm{c} . \mathrm{E}$

$\pi \quad=\quad \mathrm{p} \quad\left(\mathrm{aE} \quad-\quad \mathrm{bE}^{2}\right) \quad-$ $\mathrm{cE}$

(6)

Hasil Dan Pembahasan

Keadaan Umum Sumberdaya Perikanan

Menurut data dari Dinas Perikanan dan Kelautan Kabupaten Maluku Tengah Tengah tahun 2011, kekayaan sumberdaya perikanan dengan nilai standing stock sebesar 10.768,64 ton/tahun dan potensi pemanfaatan lestari atau Maximum sustainable Yield (MSY) sebesar 5.384,32 ton/tahun dan jumlah tangkapan diperbolehkan (JTB) sebesar 4.307,46 ton/tahun. Perkembangan produksi perikanan Kabupaten Maluku Tengah Tahun 2005 - 2011 dapat dilihat pada Tabel 1. 
Tabel 1. Produksi Perikanan Tahun 2005 2011 Kabupaten Maluku Tengah.

No Kecamatan Produksi (Ton)/Tahun

\begin{tabular}{|c|c|c|c|c|c|c|c|c|}
\hline No & Kecamatan & \multicolumn{7}{|c|}{ Produksi (Ton)/Tahun } \\
\hline & & $\begin{array}{r}200 \\
5\end{array}$ & 2006 & 2007 & $\begin{array}{c}200 \\
8\end{array}$ & 2009 & $\begin{array}{c}201 \\
0\end{array}$ & $\begin{array}{c}201 \\
1\end{array}$ \\
\hline 1. & TNS & 35,6 & 35,6 & 62,8 & $\begin{array}{c}74, \\
3\end{array}$ & 86,3 & $\begin{array}{c}99 \\
1\end{array}$ & $\begin{array}{c}230 \text {, } \\
07\end{array}$ \\
\hline 2 & Banda & $\begin{array}{r}2.66 \\
0,3\end{array}$ & $\begin{array}{r}2.660 \\
3\end{array}$ & $\begin{array}{r}8.854, \\
0\end{array}$ & $\begin{array}{c}10 . \\
472 \\
, 9\end{array}$ & $\begin{array}{c}8.869, \\
0\end{array}$ & $\begin{array}{c}10 . \\
191 \\
, 7\end{array}$ & $\begin{array}{l}11.7 \\
28,7 \\
8\end{array}$ \\
\hline 3 & Saparua & $\begin{array}{r}3.23 \\
5,7\end{array}$ & $\begin{array}{r}3.235 \\
7\end{array}$ & $\begin{array}{r}7.731, \\
0\end{array}$ & $\begin{array}{c}9.1 \\
44 \\
4\end{array}$ & $\begin{array}{c}7.656, \\
0\end{array}$ & $\begin{array}{c}8.7 \\
97, \\
0\end{array}$ & $\begin{array}{l}10.1 \\
14,9 \\
2\end{array}$ \\
\hline 4 & P.Haruku & $\begin{array}{r}2.67 \\
5,2\end{array}$ & $\begin{array}{r}2.675 \\
2\end{array}$ & $\begin{array}{r}5.731, \\
0\end{array}$ & $\begin{array}{c}6.7 \\
78 \\
9\end{array}$ & $\begin{array}{c}4.763, \\
0\end{array}$ & $\begin{array}{c}5.4 \\
73 \\
4\end{array}$ & $\begin{array}{l}6.29 \\
5,34\end{array}$ \\
\hline 5 & Leihitu & $\begin{array}{r}9.73 \\
5,0\end{array}$ & $\begin{array}{r}9.735 \\
0\end{array}$ & $\begin{array}{r}14.474 \\
, 2\end{array}$ & $\begin{array}{c}11 . \\
948 \\
, 5\end{array}$ & $\begin{array}{c}9.256, \\
9\end{array}$ & $\begin{array}{c}10 . \\
637 \\
, 5\end{array}$ & $\begin{array}{l}12.2 \\
31,1 \\
1\end{array}$ \\
\hline 6 & $\begin{array}{l}\text { Leihitu } \\
\text { Barat }\end{array}$ & - & - & - & $\begin{array}{c}5.1 \\
36, \\
3\end{array}$ & $\begin{array}{c}1.542, \\
0\end{array}$ & $\begin{array}{c}1.7 \\
72 \\
0\end{array}$ & $\begin{array}{l}2.03 \\
8.44\end{array}$ \\
\hline 7 & Salahutu & $\begin{array}{r}6.55 \\
1,5\end{array}$ & $\begin{array}{r}6.551, \\
5\end{array}$ & 11.450 & $\begin{array}{c}3 . \\
543 \\
, 8\end{array}$ & $\begin{array}{c}9.475, \\
2\end{array}$ & $\begin{array}{c}10 . \\
888 \\
, 3\end{array}$ & $\begin{array}{l}12.5 \\
20,5 \\
5\end{array}$ \\
\hline 8 & Amahai & $\begin{array}{r}3.59 \\
1,9\end{array}$ & $\begin{array}{r}3.591 \\
9\end{array}$ & $\begin{array}{r}9.753, \\
0\end{array}$ & $\begin{array}{c}8.0 \\
81, \\
5\end{array}$ & $\begin{array}{c}5.858, \\
4\end{array}$ & $\begin{array}{c}6.7 \\
36 \\
5\end{array}$ & $\begin{array}{l}7.73 \\
2,04\end{array}$ \\
\hline 9 & $\begin{array}{l}\text { Teluk } \\
\text { Elpaputih }\end{array}$ & - & - & - & $\begin{array}{c}12 . \\
364 \\
, 9\end{array}$ & $\begin{array}{c}2.125, \\
1\end{array}$ & $\begin{array}{c}2.4 \\
42, \\
0\end{array}$ & $\begin{array}{l}2.80 \\
7,89\end{array}$ \\
\hline 10 & Tehoru & $\begin{array}{r}2.54 \\
3,7\end{array}$ & $\begin{array}{r}2.543 \\
7\end{array}$ & $\begin{array}{r}10.453 \\
, 5\end{array}$ & $\begin{array}{c}4.4 \\
17 \\
5\end{array}$ & $\begin{array}{c}9.454, \\
3\end{array}$ & $\begin{array}{c}10 . \\
862 \\
, 2\end{array}$ & $\begin{array}{l}6.86 \\
9,31\end{array}$ \\
\hline 11 & Teluti & - & - & - & - & - & - & $\begin{array}{l}5.62 \\
0,18\end{array}$ \\
\hline 12 & Seram Utara & $\begin{array}{r}1.77 \\
3,7\end{array}$ & $\begin{array}{r}1.773 \\
7\end{array}$ & $\begin{array}{r}5.054, \\
7\end{array}$ & $\begin{array}{c}1.9 \\
46 \\
1\end{array}$ & $\begin{array}{c}1.465, \\
3\end{array}$ & $\begin{array}{c}1.5 \\
57 \\
7\end{array}$ & $\begin{array}{l}2.02 \\
8,86\end{array}$ \\
\hline 13 & $\begin{array}{ll}\text { S. } & \text { Utara } \\
\text { Kobi } & \end{array}$ & - & - & - & - & - & - & $\begin{array}{c}84,6 \\
8\end{array}$ \\
\hline 14 & S. Utara Seti & - & - & - & - & - & - & $\begin{array}{l}56,4 \\
5\end{array}$ \\
\hline 15. & $\begin{array}{ll}\text { S. } & \text { Utara } \\
\text { Barat } & \end{array}$ & - & - & - & $\begin{array}{c}3.4 \\
96, \\
4\end{array}$ & $\begin{array}{c}1.270, \\
3\end{array}$ & $\begin{array}{c}1.4 \\
59 \\
8\end{array}$ & $\begin{array}{l}1.67 \\
8,44\end{array}$ \\
\hline 16 & Nusa laut & $\begin{array}{r}1.54 \\
7,5\end{array}$ & - & $\begin{array}{r}3,827, \\
5\end{array}$ & $\begin{array}{c}3.4 \\
96, \\
4\end{array}$ & $\begin{array}{c}1.827, \\
5\end{array}$ & $\begin{array}{c}2.1 \\
00 \\
1\end{array}$ & $\begin{array}{l}2.41 \\
4,67\end{array}$ \\
\hline 17 & Kota Masohi & $\begin{array}{r}6.95 \\
7,0\end{array}$ & - & $\begin{array}{r}10.761 \\
, 1\end{array}$ & $\begin{array}{l}12 . \\
728 \\
, 7\end{array}$ & $\begin{array}{c}8.961, \\
1\end{array}$ & $\begin{array}{c}10 . \\
297 \\
, 6\end{array}$ & $\begin{array}{l}11.8 \\
40,2 \\
7\end{array}$ \\
\hline & Jumlah & $\begin{array}{l}41.3 \\
07,1\end{array}$ & $\begin{array}{r}41.307 \\
, 1\end{array}$ & $\begin{array}{r}88.153 \\
, 0\end{array}$ & $\begin{array}{l}104 \\
.66\end{array}$ & $\begin{array}{l}72.610 \\
, 3\end{array}$ & $\begin{array}{r}83 . \\
314\end{array}$ & $\begin{array}{l}96.2 \\
92,0\end{array}$ \\
\hline
\end{tabular}

Dari tabel di atas dapat dilihat bahwa produksi perikanan tangkap di Kecamatan Tehoru mencapai produksi tertinggi pada tahun 2010 dengan persentase $13,04 \%$ dan produksi terendah pada tahun 2005 dan 2006 dengan persentase sebesar 6,16 \%. Data ini menunjukan bahwa produksi perikanan tangkap di Kecamatan Tehoru relatif berfluktuasi. Hal ini didukung dengan berkurangnya jumlah nelayan yang melakukan usaha penangkapan ikan di Kecamatan Tehoru yaitu pada tahun 2010 jumlah nelayan 1.500 orang sedangkan tahun 2011 jumlah nelayan mengalami penurunan sebesar 832 orang (DKP Malteng, 2011).

Nelayan di perairan Wilayah Kecamatan Tehoru menangkap jenis ikan pelagis kecil seperti seperti selar (Selaroides sp , Selar sp), ikan komu (Euthynus sp), kawalinya (Selar sp), momar (Decapteus sp) dan lema (Rastrelliger sp). Potensi ikan pelagis kecil di daerah penangkapan wilayah ini yakni sebesar 731,34 ton dengan MSY sebesar 301 ton/tahun dan jumlah tangkapan 
diperbolehkan sebesar 295,53 ton/tahun. Jenis ikan pelagis besar yang tertangkap di perairan wilayah Kecamatan Tehoru terdiri dari ikan cakalang (Katsuwonus pelamis) dan ikan tuna (Thunnus spp). Potensi ikan pelagis besar pada wilayah kelola $0-4$ mil laut, diestimasi sebesar 376,50 ton dengan pemanfaat maksimum (MSY) sebesar 188,25 ton/tahun dan jumlah tangkapan diperbolehkan (JTB) sebesar 150,60 ton/tahun. Potensi ikan pelagis besar pada wilayah kelola 4-12 mil laut, diperkirakan sebesar 590,28 ton dengan pemanfaat maksimum (MSY) sebesar 295,14 ton/tahun dan jumlah tangkapan diperbolehkan (JTB) sebesar 236,11 ton/tahun (DKP Maluku Tengah, 2011). Potensi ikan demersal di perairan Kecamatan Tehoru yakni sebesar 368,21 dengan MSY sebesar 184,11 ton/tahun dan jumlah tangkapan yang diperbolehkan sebesar 147,28 ton/tahun.

\section{Produksi}

Purse seine yang dioperasikan di Kecamatan Tehoru ditujukan untuk menangkap gerombolan ikan - ikan pelagis. Untuk rata - rata hasil tangkapan yang diperoleh paling dominan adalah jenis ikan momar. Rata - rata produksi per tahun untuk 9 unit purse seine tiap operasi penangkapan menghasilkan 143,55 ton (momar, tuna , cakalang, komu, kawalinya dan lamadang) dengan harga ikan disesuaikan menurut size (ukuran) yang telah ditetapkan oleh PT. ATM diantaranya; ikan momar (Size 40 -90) dinilai dengan harga Rp 5.500,- , ikan momar (Size 95 - 120) dinilai dengan harga Rp 4.500,- ikan momar (Size 121 200) dan ikan cakalang kecil dinilai dengan harga $\mathrm{Rp} 3.000$,- per $\mathrm{kg}$, ikan lamadang dinilai dengan harga Rp 1.500,per kg dan ikan tuna harga per ekor ukuran kecil dihargai sebesar Rp 4.000,-. Para nelayan pada umumnya menjual hasil tangkapan kepada kapal jpenampung untuk diekspor ke Jepang dan dijual lokal ke Banyuwangi.

Aspek Biologis Sumberdaya Ikan Pelagis

Salah satu aspek biologi dalam pengelolaan sumberdaya ikan pelagis kecil adalah ketersediaan potensi sumberdaya ikan. Jika sumberdaya ikan masih tersedia maka usaha penangkapan ikan pelagis kecil dengan pukat cincin ( purse seine) dapat dilakukan.

Hasil tangkapan pukat cincin (purse seine) merupakan jenis ikan - ikan pelagis 
yang membentuk gerombolan (schooling). Penangkapan ikan oleh nelayan purse seine di Kecamatan Tehoru dari tahun ketahun cenderung mengalami peningkatan. Peningkatan CPUE dalam kegiatan penangkapan nelayan purse seine disebabkan oleh terjadinya peningkatan produksi dan penurunan jumlah unit armada penangkapan.

Pada tahun 2005 dan 2006 terjadi effort terendah dan produksi tertinggi, sedangkan CPUE tertinggi. CPUE terendah terjadi pada tahun 2007 dan 2008, sementara produksi tertinggi terjadi pada tahun 2005 dengan effort 90 trip per tahun. Perkembangan produksi, upaya penangkapan dan CPUE dapat dilihat pada Tabel 2.

Tabel 2. Perkembangan Produksi, Upaya Tangkap dan CPUE

ikan pelagis Kecil Periode Tahun 2005 - 2011.

$\begin{array}{lccccc}\text { Tahun } & \begin{array}{c}\text { Produksi } \\ (\mathrm{Kg})\end{array} & \begin{array}{c}\text { Produksi } \\ \text { (Ton) }\end{array} & \begin{array}{c}\text { Effort } \\ (\text { Trip })\end{array} & \begin{array}{c}\text { CPUE } \\ (\mathrm{Kg})\end{array} & \begin{array}{c}\text { CPUE } \\ (\text { Ton })\end{array} \\ 2005 & 437.530 & 437,530 & 90 & 4.861 & 4,861 \\ 2006 & 421.679 & 421,679 & 106 & 3.978 & 3,978 \\ 2007 & 154.243 & 154,243 & 103 & 1.498 & 1,498 \\ 2008 & 136.579 & 136,579 & 105 & 1.301 & 1,301 \\ 2009 & 156.280 & 156,28 & 171 & 914 & 0,914 \\ 2010 & 181.950 & 181,95 & 173 & 1.052 & 1,052 \\ 2011 & 193.750 & 193,75 & 174 & 1.113 & 1,113\end{array}$

Sumber : Dinas Perikanan dan Kelautan Kabupaten Maluku Tengah Tahun, 2011.

Berdasarkan perhitungan hubungan antara CPUE dan effort purse seine dalam pemanfaatan sumberdaya ikan pelagis kecil, diperoleh nilai intersep (a) sebesar 5,865 dan koefisien independent (b) sebesar -0,0286. Secara matematis hubungan antara CPUE dengan effort pukat cincin (purse seine) dapat dinyatakan sebagai berikut CPUE $=2,93$ ton/hari kapal. Hubungan antara hasil dengan effort yang lebih dikenal sebagai fungsi produksi lestari dapat dinyatakan sebagai berikut $\mathrm{h}=301$ ton/tahun.

Selanjutnya dengan menggunakan program Aplikasi Excel, maka dapat diketahui effort pada tingkat produksi lestari maksimum (Emsy) purse seine sebesar 103 trip per tahun.

Perhitungan matematis hasil tangkapan pada kondisi MSY di peroleh sebesar $\quad 301$ ton per tahun. Nilai hmsy menunjukkan tingkat produksi maksimum lestari yaitu hasil tangkapan ikan pelagis kecil tertinggi yang dapat ditangkap tanpa mengancam kelestarian sumberdaya perikanan yang terdapat di perairan Kecamatan Tehoru. Hubungan kuadratik antara upaya penangkapan purse 
seine dengan hasil tangkapan ikan pelagis kecil di Kecamatan Tehoru dapat dilihat pada Gambar 1.

$\begin{array}{rrr} & \text { Berdasarkan Gambar terlihat } \\ \text { bahwa hubungan antara upaya }\end{array}$
penangkapan purse seine dan hasil tangkapan ikan pelagis kecil di Kecamatan Tehoru berbentuk parabola (fungsi kuadratik), artinya setiap penambahan tingkat upaya penangkapan (E) maka akan meningkatkan hasil tangkapan (h) sampai mencapai titik maksimum, kemudian akan terjadi penurunan hasil tangkapan untuk tiap peningkatan intensitas pengusahaan sumberdaya.

Gambar 1. Hubungan Produksi Sumberdaya Pelagis Kecil dan Upaya

Penangkapan dengan Model Schaefer.

\section{Analisis MEY}

Analisis MEY digunakan untuk mengukur tingkat keuntungan maksimal yang diperoleh pada saat produksi tertentu. Apabila penangkapan melebihi MEY (Maximum Economic Yield/Hasil Tangkapan Maksimum secara Ekonomis) maka keuntungan akan semakin berkurang. Oleh karena itu pemanfaatan sumberdaya secara berlebihan akan berakibat hilangnya manfaat ekonomi bagi nelayan yang melakukan penangkapan ikan. Data jumlah hasil tangkapan, jumlah trip, TR, TC dan keuntungan ikan pelagis kecil per tahun diuraikan pada Tabel 3 .

Tabel 3. Pendugaan Parameter Ekonomi Unit Purse Seine Kecamatan Tehoru

Sumber: Data primer yang diolah, 2012.

Berdasarkan Tabel diatas harga ikan dalam penelitian ini diasumsikan bersifat konstan yang dianut model Gordon - Schaefer. Rata - rata harga jual hasil tangkapan per kilogram pada Musim Barat dan Musim Timur yang telah ditetapkan oleh Perusahaan Anugerah Tehoru Manise (PT. ATM) berkisar diantaranya; harga Rp 1.500,- sampai harga 5.500,- per kg. Untuk rata - rata harga $(\mathrm{p})$ pendugaan parameter ekonomi sebesar 3.500 per kg. Analisis MEY dilakukan berdasarkan nilai $\alpha$ dan $\beta$ hasil regresi linear Model Schaefer yang juga dipergunakan untuk analisis MSY, 
dengan nilai intersep (a) sebesar 5,865 dan koefisien independent (b) sebesar -0,0286.

Hasil analisis Maximum Economic Yield (MEY) untuk ikan pelagis di Kecamatan Tehoru menunjukkan produksi optimum sebanyak $299 \mathrm{~kg}$ pertahun dan Effort Maximum Economic Yield (EMEY) 99,85 trip per tahun jumlah trip penangkapan. Pendapatan total (TR) yang dapat diperoleh pada posisi MEY (Maximum Economi Yield) sebesar $\mathrm{Rp}$ 841.005.500,- dengan total biaya (TC) sebesar Rp 883.814.285,7 Sehingga total keuntungan yang mampu dihasilkan $\mathrm{Rp}$ 59.173.357,14.

Gambar 2. Hubungan TR dan TC

Hubungan TR dan TC Penangkapan ikan pelagis kecil menunjukkan kondisi MEY terjadi jika biaya (TC) yang diperoleh lebih besar daripada pendapatan (TR) yang dikeluarkan oleh nelayan sehingga mendapatkan kerugian yang kecil sampai Rp 59.173.357,14 pada titik EMEY (99,85 trip).

Kesimpulan
Tingkat produksi optimal pada pemanfaatan sumberdaya ikan pelagis kecil MSY di peroleh sebesar 301 ton per tahun dengan (Emsy) purse seine sebesar 103 trip per tahun. Hasil analisis Maximum Economic Yield (MEY) untuk ikan pelagis kecil di Kecamatan Tehoru menunjukkan produksi optimum sebanyak $299 \mathrm{~kg}$ pertahun dan Effort Maximum Economic Yield (EMEY) 99,85 trip per tahun jumlah trip penangkapan dengan MEY menunjukkan produksi optimum sebanyak $299 \mathrm{~kg}$ pertahun.

\section{DAFTAR PUSTAKA}

Badan Pusat Statistik. 2011. Klasifikasi Baku Lapangan Usaha Indonesia (KBLI, 2009) Bidang Kelautan dan

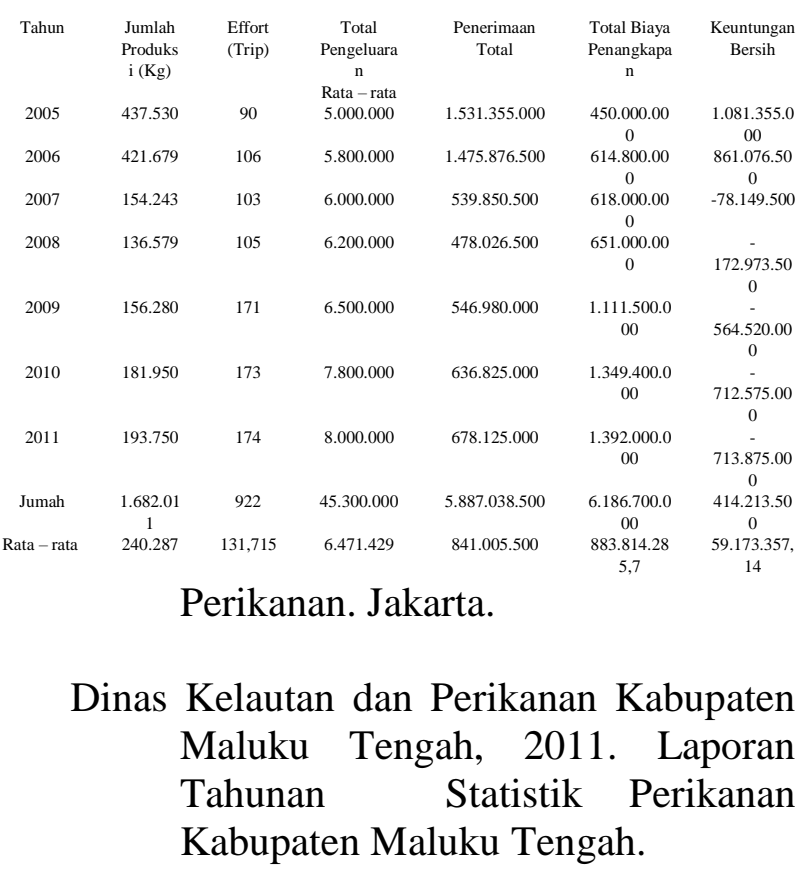


Direktorat Jendral Perikanan Departemen Pertanian. 1994. Ikan - Ikan Ekonomis penting di Indonesia (Gambar). Pusat Penelitian dan Pengembangan Pertanian, Departemen Pertanian.

Dirjen Perikanan Tangkap, 2004. Kebijakan Pembangunan Perikanan Tangkap. Disampaikan Pada Rapat Koordinasi Relokasi Nelayan Tingkat Nasional Tahun 2004 Tanggal 9 - 10 Desember 2004. Dirjen Perikanan Tangkap Departemen Kelautan Perikanan. Jakarta. 4 halHiariey, J. 2010. Materi Kuliah Ekonomi Sumberdaya Alam dan Lingkungan. Fakultas Perikanan dan Ilmu Kelautan Universitas Pattimura. Ambon

Mulyana, Ridwan. 2007. Pengelolaan Perikanan dan Teori Perizinan.Subdit Pemantauan dan Evaluasi, Direktorat PUP, Dirjen PerikananTangkap.

Nabunome, Welhelmus, 2007. Model Analisis Bioekonomi dan Pengelolaan Sumberdaya Ikan Demersal (Studi empiris Kota Tegal, Jawa Tengah).Thesis S2 Program Pasca Sarjana Universitas Diponegoro (tidak dipublikasikan).

Nybakken, J.W. 1989. Biologi Laut: Suatu Pendekatan Ekologis. PT. Gramedia, Jakarta.

Riduwan, 2004. Metode dan Teknik Menyusun Tesis. Penerbit Alfabeta. Bandung. Universitas Gajah Mada. Yogyakarta.
Siagian, D. dan Sugiarto, 2006. Metode Statistika Untuk Bisnis Dan Ekonomi. Penerbit PT Gramedia Pustaka Utama. Jakarta.

Singarimbun, M. dan Sofian Efendi, 2008. Metode Penelitian Survai (Ed Revisi), Lembaga Penelitian Pendidikan dan Penerangan Ekonomi dan Sosial (LP3ES) Jakarta.

Sudirman, H dan A. Mallawa. 2004. Teknik Penangkapan Ikan. Penerbit Rineka Cipta. Jakarta.

Suharno. 2008. Analisis Sumberdaya Udang Dengan Model Bioekonomi Pada Nelayan Trammel Net Di Kabupaten Cilacap, Provinsi Jawa Tengah. Thesis S2

Program PascaSarjana Universitas Diponegoro. Semarang. (tidak dipublikasikan).

Jones, Rowan \& Maurice Pendlebury. 1996. Public Sector Accounting. Fifth Edition. London: Pitman.

Badan Pemeriksa Keuangan 2016. Ikhtisar Hasil Pemeriksaan Semester 1 Tahun 2016. Melalui http://www. bpk. go. id diunduh tanggal $15 \mathrm{Mei}$ 2016.

Republik Indonesia, Undang-Undang Nomor 17 Tahun 2003 tentang Keuangan Negara.

Peraturan Pemerintah Nomor 24 Tahun 2005 tentang Standar Akuntansi Pemerintahan.

Nomor 56 Tahun 2005 tentang 
Sistem Informasi Keuangan

Daerah.

Peraturan Pemerintah

Nomor 71 Tahun 2010 tentang

Standar Akuntansi Pemerintahan.

Peraturan Menteri Dalam

Negeri Nomor 13 Tahun 2006

tentang Pedoman Pengelolaan Keuangan Daerah.

-------, Peraturan Pemerintah

Nomor 60 Tahun 2008 tentang

Sistem Pengendalian Intern

Jenderal Departemen Keuangan terkait dengan Perwujudan Peran Aparat Pengawasan Internal yang Efektif.

http://www.itjen.kemenkeu.go.id/b aca/77

.Wahana Komputer. 2003. Panduan Aplikatif Sistem Akuntansi Online Berbasis Komputer. Penerbit ANDI, Yogyakarta. 